INDEPENDENT JOURNAL OF MANAGEMENT \& PRODUCTION (IJM\&P) http://www.ijmp.jor.br

v. 12, n. 7, September-October 2021

ISSN: 2236-269X

DOI: 10.14807/ijmp.v12i7.1473

\title{
IMPACT OF CORPORATE GOVERNANCE ON BANK PROFITABILITY - POST REFORMS BY RBI AND SEBI
}

\author{
Riya Anil Rai \\ Symbiosis Institute of Business Management (SIBM) Symbiosis \\ International (Deemed University) (SIU), India \\ E-mail:riya.rai21@sibm.edu.in
}

Submission: $10 / 22 / 2020$

Revision:11/27/2020

Accept: 11/11/2020

\section{ABSTRACT}

In India, the increasing awareness with respect to CG, particularly in the commercial banking industry can be attached to a variety of factors such as liberalization, scams, corporate failures in banks, accounting and other irregularities that have led to an era of rising public distrust of the governance process in the banking landscape. Because of economic problems arising out of banking mis-management and failures, studies on bank profitability have become imperative for recognizing problems and mitigating economic risks. Over the last few years, Indian banks' toxic loan pile has increased considerably in addition to frequent instances of governance lapses being identified by the regulator. Indian banks' failure to adhere to acceptable business practices has unraveled a chain of events that have caused distress to the public causing the regulator to overhaul its outlook towards CG in banks and decision to infuse capital in the banking sector to revive it. The study attempts to assess the relation between governance and other factors' impact on the bank profitability with empirical evidence from Axis, HDFC, ICICI, PNB, SBI and Yes Bank. The study outlines links between the Bank's Size, Board Independence, Independence of Audit Committee, Audit Committee Strength, Duality of Role, NPA Divergence and profit by using Return on Equity, Return on Assets and Net Interest Margin as proxies for measuring profitability. The findings indicate that Audit Committee Independence, Audit Committee Strength had a statistically significant impact on bank profits, while Bank Size had a negative affiliation to profits as per all three indicators of profits.

Keywords: Corporate Governance, Bank Profits, Return on Equity, Return on Assets, Net Interest Margin 
ISSN: 2236-269X

DOI: 10.14807/ijmp.v12i7.1473

\section{INTRODUCTION}

Banks perform a crucial role of channelizing funds from depositors to activities that support the nation's economy and aid in steering growth of a nation. Sound functioning and safety of banks are critical to financial stability, and the way they carry out business thus becomes central to the state of the nation's economic health. Governance weaknesses if not controlled can have a serious consequences on health of the financial system causing widespread effect ranging from the commercial banking segment to the national economy.

The Basel Committee on Banking Supervision (BCBS) outlined the urgent need to analyze and improve Corporate Governance (referred to as CG hereafter) of the financial institutions. An ideal governance structure has been recommended by the comprising of a Board of Directors (BoD) and senior executives. Moreover, the body asserts that CG is an essential element to ensure a well-rounded financially sound banking system and, therefore, of a nation's economic development.

Banks generally function under an umbrella of public surveillance in the face of supervisors, banking laws and regulators that monitor its conduct. The interplay amongst all of these factors determines to what extent the performance of a bank in terms of profit, will satisfy the desires of its stakeholders, while ensuring compliance with public expectations at large. For shareholders, investors and regulators thus, the CG structure is a matter of significant consequence in a bank's success and its daily functioning.

Failure to adopt and implement ideal practices in CG and the lack or absence of effective working controls are among the most important characteristics that threaten the profitability and solvency of a bank. Therefore, deeper understanding of CG of banks is relevant for the sole reason that banks pose systematic risk for the economy as demonstrated in 1980's by the savings and loan crisis in the U.S. in the 1990's by, the Asian financial crisis in 2000's, by the mortgage crisis and more recently in the latter half of 2010's by the Indian Bank crisis and the recapitalization project that the Government of India has undertaken to clean up the bad loans from the banks.

Consequent to opening up of the Indian economy post 1991, when Liberalization, Privatization and Globalization (LPG) were initiated by the then Government of India, CG issues has gained focus in India, slowly but steadily. Introduction of Companies Act, 2013, witnessed a significant rise in listed companies' adherence to CG issues, as the law mandated it and regulator Securities and Exchange Board of India (SEBI) enforced adherence to the 
DOI: 10.14807/ijmp.v12i7.1473

requirements prescribed in the act (Venkateshwaran, Arora \& Rastogi, 2018). A third major implication on CG in India was because of the Uday Kotak committee constituted by SEBI in 2017. It made recommendations pertaining to the role duality of Chairman and Managing director, number of women directors and independent directors on the board, related party transactions and effectiveness of board practices.

A string of regulatory and structural reforms promoted the importance of CG of Indian banking sector. These measures mandated the banks to bring up their ratio of non-executive, non-promoter directors on the boards; introduce members to board who come with rich expertise and diverse portfolio of skill set; and instating board committees for critical functions such as risk oversight, remuneration, nomination, grievance redressal.

These reforms were spearheaded by the enactment of recommendations proposed by Ganguly Committee with respect of $\mathrm{BoD}$ in terms of roles and responsibilities, training to directors, and application of 'fit and proper' norms for directors. Recently, the Reserve Bank of India (RBI) has unearthed a series of massive lapse in control practices adopted by several large banks that have led to an increase in the loss of shareholders wealth, skyrocketing growth in the amount of bad loans reported by the banks. Such lapses pose serious threat to a common depositor's savings and wealth (Kanungo \& Dash, 2016).

This literature aims to establish an empirical link between the governance practices, and the profits of the chosen banks reported through the years 2014-15 to 2018-19. All of the study has been done in the Indian perspective. The banks selected for this study are chosen on the basis of their scale of operations, customers catered, size of the assets, etc.; namely, Axis, HDFC, ICICI, PNB, SBI and Yes Bank. 4 out of the 6 banks have been penalized by the regulator for failing to comply with the desirable governance practices as laid out in the Clause 49 of the SEBI Listing Agreement and Companies Act, 2013.

Out of the 6 selected banks, 2 are public sector banks governed by the regulations they were incorporated under, namely, State Bank of India (SBI), through the SBI Act, 1955 and amendments therein and Punjab National Bank (PNB) under the Banking Companies (Acquisition and Transfer of Undertakings) Act, 1970; and the Bank Nationalization Act, 1980. The rest 4 private sector banks are governed under the Banking Regulation Act, 1949, Companies Act, 2013 and the SEBI Listing Obligation and Disclosure Requirements 2015.

\section{REVIEW OF LITERATURE}


INDEPENDENT JOURNAL OF MANAGEMENT \& PRODUCTION (IJM\&P)

http://www.ijmp.jor.br

v. 12, n. 7, September-October 2021

ISSN: $2236-269 X$

DOI: 10.14807/ijmp.v12i7.1473

The issue of CG in banks has been recognized as a matter requiring urgent attention, globally. Organization for Economic Co-operation and Development (OECD) principles have set background for measuring CG practices in a country, while BCBS has listed CG measures for commercial banks. Following the recommendation of the BCBS, OECD most nations have taken up plans to improve the CG norms particularly in the banking sector.

Pati (2006) opines that the implementation of CG policies in Indian banking sector, undertaken in the wake of the recommendations by the Advisory Group, 2001; under the chairmanship of R.H. Patil, has brought blended results as most banks reported improved profit and low NPAs. Bank centric CG practices are expected to have an impact on the profits of banks. Hence, approaches that directly influence the essential functions of the bank will therefore have a relationship with the governance. Most studies on the subject of CG have been theoretical, with only a few of them encompassing the commercial banks. Additionally, there is little data-based evidence available in the research literature for CG in the banking sector.

Fanta (2013) examined CG mechanisms and traced their relationship with bank performance in absence of an organized stock exchange. The literature measured the interrelation among a few selected internal and extrinsic CG structures, and used ROA and ROE as proxies for bank performance. The results showed that board size and presence of audit committee on the board; bank size had significant effect on bank profits. (HifzaInam \& Mukhtar, 2014) state that good governance is a must have in order to improve the asset quality of banks, and thereby draw a positive relationship between the two.

This establishes a positive link between operational efficiency and CG. It further goes on to state that privatization could be used as a metric to measure bank performance and concludes by saying that privately owned and managed banks have better control over their CG compliance in contrast to government owned banks, and that there exists notable interrelation between promoter holding of banks and CG.

In their research, Paul and Simon (2014) conclude that variables indicative of CG practices such as Composition of $\mathrm{BoD}$, size of $\mathrm{BoD}$, Independence of $\mathrm{AC}$ and separation of supervisory and executive role are not the sole drivers for the increasing levels of NPAs in Nigerian Banks and therefore suggest heavier emphasis to be towards internal controls and transparency in the operations, accountability and so on. Zhen and Rui (2010) carried out a study on 11 commercial banks between the period 2004-08 to understand the impact of risk 


\section{INDEPENDENT JOURNAL OF MANAGEMENT \& PRODUCTION (IJM\&P)}

http://www.ijmp.jor.br

v. 12, n. 7, September-October 2021

ISSN: 2236-269X

DOI: 10.14807/ijmp.v12i7.1473

aversion, particularly of credit in the banks and found that higher the bank's ownership consolidation, the higher the NPA ratio.

Ennobakhare (2010) studied the affiliation between CG practices and bank profitability to find that there exists is a direct interrelation between the day-to-day operation and the CG compliance practices. In his study, he proves that the ownership pattern of banks has a direct relationship with the performance of NPA in banks. In their research based on Nigerian banks, Nyor and Mejabi (2013) studied the effect of CG practices on NPAs of Banks and found that CG variables such as number of members on BoD, Independence of BoD, number of Audit Committee members and Power Separation did not have any direct correlation with NPA. Moreover, they went on to suggest that these variables are unreliable to be used for the purpose of NPA management and recommended further research on other CG related variables like transparency in financial statements, disclosure policies and accountability apart from the aforementioned variables.

In the Indian context Goel (2014) studied the implication of CG practices on NPAs of bank advances and asserts that, the foremost cause for increasing losses of banks in the contemporary past were the NPAs. She further adds, CG and NPAs are highly relates and no significant research efforts have been made to establish the association between CG and NPAs.

Brahmaiah and Ranajee (2018) examined probable factors that influenced the profits of Indian banks following increased globalization, growing competition, and ownership consolidation. The study analyzed banks profits through ROA and ROE for sample of 89 Indian banks for the period 2005 to 2015. Results revealed that profit-making of banks is affected by both internal and external factors.

As stated by Zafar, Maqbool and Khalid (2013) in their study, PSBs are most plagued with the bad loan pile followed by privately owned banks, and then foreign banks. NPAs mirror the financial accomplishment of banks and management's failure to reduce NPAs adversely affects profits. As per Prasad and Veena (2011), “The Public Sector Banks, which are perceived as the foundation of the Indian Banking system, are unfortunately burdened with excessive Non Performing Assets (NPA), huge manpower and lack of advanced technology”.

Joseph and Prakash (2014) recommend that, banks maintain a proactive approach in adopting and implementing a practical and structured NPA management system with the aim of preventing loans from turning into NPA. The study also highlights that public sector banks 
report higher NPAs in comparison to their privately owned counterparts and suggest that public sector bank (PSBs) take stringent preventive measure to avoid loan/ advances leading to NPA.

Balasubramaniam (2001) studied NPAs and profits of commercial banks in India and highlighted that NPA levels of Indian banks are at an all time high. The study suggests that, effectively active internal financial controls, robust credit disbursal system, along with ongoing asset quality improvement measures will reduce the amount of NPAs in banking sector.

In a comparison study of banks Chaudhary and Sharma (2011) analyzed the performance of private and state-owned banks and suggested that NPA problems must be dealt with, with utmost stringent measures in order to clear the bad loan pile of the banks. The authors suggest adoption of real-time information tracking system for training the bank staff and ensuring robust documentation prior to credit sanction to borrowers, with special focus on verifying the legitimacy of verifying documentation produce.

Since the responsibility lies with the bank staffs to be vigilant when processing credit, it is imperative that they are motivated to take preventive steps to keep from advances turning into NPA. Additionally, PSBs were suggested to focus on their operations to match their checks with those of private sector banks. According to a report published in the Mint by Rajwade (2014), NPA levels in PSBs have mirrored the poor CG practices and that there is need for an overhaul in the selection of the board members giving more importance to maintaining a board and management comprised of executives with greater expertise and diverse skill set.

The same issue has been highlighted by Nworji, Adebayo and Adeyanju (2011) in their research that the persistent rise in NPLs of Nigerian Banks has posed serious question marks on the consistency in implementation of the CG compliance. In an interview by Chakrabarty (2014), Former Deputy Governor of Reserve Bank of India, commented that CG, answerability and standard of executives are amongst the most potent elements responsible to combat the NPA problem in case of the privately owned banks. To add emphasis to his previous statement he describes Non-performing assets as a challenge arising from "Non-Performing Administration”.

\section{DATA AND RESEARCH METHODOLOGY}

\subsection{Sample selection and Data Source}

Here, a sample of 6 Indian banks has been picked for the purpose of this study. 2 Public Sector banks have been selected from a universe of 12 PSBs; whereas 4 Private Sector Banks have been chosen out of 22. The period of study is from Fiscal Year (FY) 2014-15 to FY 2018- 
ISSN: 2236-269X

DOI: 10.14807/ijmp.v12i7.1473

19. A total of 30 observations for 6 companies were taken in the study for evaluating affiliation for the response (dependent) and explanatory (independent) variables. The data has been extracted from Prowess Data Extraction or better known as Prowessdx, a database maintained by Centre for Monitoring the Indian Economy (CMIE). Furthermore, statistics was also gathered from annual reports of the banks and credible sources such as RBI publications and filings.

\subsection{Variables Construction}

\subsubsection{Response Variables}

The response variables or the dependent variables selected in the study are the indicators used to measure profitability of the banks. I have selected ROE, and ROA and NIM. Table 1 contains the description for the response variables.

\begin{tabular}{ccc}
\hline Variable Acronym & Variable Name & Definition \\
\hline NIM & Net Interest Margin & Net Interest Income/ Average Earning Assets \\
ROE & Return on Equity & EBIT/ (Total Assets - Current Liabilities) \\
ROA & Return on Assets & PAT/ Total Assets \\
\hline
\end{tabular}

Table 1: Independent variable description

\subsubsection{Explanatory Variables}

The explanatory variables selected for the study are defined in Table 2.

\begin{tabular}{|c|c|c|}
\hline Variable Acronym & Variable Name & Definition \\
\hline $\mathrm{BCO}$ & Board Committees & Number of Board Committees \\
\hline $\mathrm{BI}$ & $\begin{array}{c}\text { Board } \\
\text { Independence }\end{array}$ & $\begin{array}{l}\text { Number of non-executive independent } \\
\text { directors }\end{array}$ \\
\hline $\mathrm{ACl}$ & $\begin{array}{l}\text { Audit Committee } \\
\text { Independence }\end{array}$ & $\begin{array}{l}\text { Number of independent board members on } \\
\text { the Audit Committee }\end{array}$ \\
\hline $\mathrm{RD}$ & Role Duality & $\begin{array}{c}\text { When the office of Chairman and Managing } \\
\text { Director (MD)/ Chief Operating Officer (CEO) } \\
\text { is held by the same person }\end{array}$ \\
\hline $\mathrm{BM}$ & Board Meetings & $\begin{array}{l}\text { Number of times the Board of Directors met } \\
\text { in a fiscal year }\end{array}$ \\
\hline
\end{tabular}

Table 2: Dependent variable description

\subsubsection{Control Variables}

From studying works of other authors in published journals, it is clear that there are other factors, apart from the explanatory variables which control or influence the profits a bank registers. These are: (i) Bank Size (BKS), taken as the natural $\log \left(l_{n}\right)$ of total assets, (ii) 
ISSN : 2236-269X

DOI: 10.14807/ijmp.v12i7.1473

Financial leverage (DC), for which the Debt-Capital ratio is taken as proxy, (iii) bad loans as a percentage of total asset book denoted by Gross Non-Performing Assets (GNPA), Net NonPerforming Assets (NNPA), Loan Write off during the year (W/O), (iv) Audit Committee Strength (ACS) denoted the total members in the committee, (v) NPA Divergence (DV) gives the difference between NPA reported by the bank and NPA identified by the regulator.

\subsection{Empirical Model}

In this empirical analysis, we built a Multi-Variate Linear Model Regression. The following regression equations were built:

$$
\begin{array}{ll}
\text { I. } & R O E=\alpha+\beta_{1} * B C O+\beta_{2} * B K S+\beta_{3} * D C+\beta_{4} * G N P A+\beta_{5} * N N P A+\beta_{6} * W O+\beta_{7} * B I \\
& +\beta_{8} * A C I+\beta_{9} * A C S+\beta_{10} * D V+\beta_{11} * R D+\beta_{12} * B M+\varepsilon
\end{array}
$$

II. $R O A=\alpha+\beta_{1} * B C O+\beta_{2} * B K S+\beta_{3} * D C+\beta_{4} * G N P A+\beta_{5} * N N P A+\beta_{6} * W O+\beta_{7} * B I$ $+\beta_{8} * A C I+\beta_{9} * A C S+\beta_{10} * D V+\beta_{11} * R D+\beta_{12} * B M+\varepsilon$

III. $\quad N I M=\alpha+\beta_{1} * B C O+\beta_{2} * B K S+\beta_{3} * D C+\beta_{4} * G N P A+\beta_{5} * N N P A+\beta_{6} * W O+\beta_{7} * B I+$ $\beta_{8} * A C I+\beta_{9} * A C S+\beta_{10} * D V+\beta_{11} * R D+\beta_{12} * B M+\varepsilon$

Here, ROE, ROA and NIM are the proxies for the measures of profits of a bank, $\alpha$ is the constant term, $\left(\beta_{1}, \beta_{2}, \beta_{3}, \beta_{4}, \beta_{5}, \beta_{6}, \beta_{7}, \beta_{8}, \beta_{9}, \beta_{10}, \beta_{11}\right.$ and $\left.\beta_{12}\right)$ are coefficients for the explanatory variables $B C O, B K S, D C$, GNPA, NNPA, WO, BI, ACI, ACS, DV, RD, and $B M$, and $\varepsilon$ is the standard error term.

The final regression model only makes use of variables that are not highly correlated to each other, (explained further in the correlation result). After removing the highly correlated variables we were left with six independent variables namely; $B K S, B I, A C S, A C I, D V$ and $R D$.

\section{Data Analysis and Findings}

\subsection{Descriptive Analysis}

Table 3 presents the descriptive statistics for all response and explanatory variables used for the purpose of this study. The dependent variables NIM, ROA and ROE have mean values of $3 \%, 1 \%$ and $8 \%$ respectively across all the banks chosen for this study between the period 2014-15 through 2018-19. We observe that for variables NIM and ROA, mean is equal to median, thereby indicating the data for NIM and ROA is normally distributed around its mean. 
DOI: 10.14807/ijmp.v12i7.1473

\begin{tabular}{|c|c|c|c|c|c|c|}
\hline \multicolumn{7}{|c|}{ Summary Statistics } \\
\hline & Mean & Standard Error & Median & Standard Deviation & Minimum & Maximum \\
\hline $\mathrm{BCO}$ & 12.87 & 0.68 & 12 & 3.73 & 10 & 22 \\
\hline BKS & 0.54 & 0.05 & 0.52 & 0.25 & 0 & 1 \\
\hline$D C$ & 0.64 & 0.01 & 0.65 & 0.07 & 0.48 & 0.8 \\
\hline GNPA & 0.06 & 0.01 & 0.05 & 0.05 & 0 & 0.19 \\
\hline NNPA & 0.03 & 0.01 & 0.02 & 0.03 & 0 & 0.11 \\
\hline wo & 0.01 & 0 & 0.01 & 0.01 & 0 & 0.03 \\
\hline BI & 0.81 & 0.01 & 0.8 & 0.06 & 0.65 & 0.92 \\
\hline $\mathrm{ACl}$ & 0.72 & 0.06 & 0.8 & 0.3 & 0.2 & 1 \\
\hline ACS & 5.2 & 0.26 & 5 & 1.4 & 3 & 8 \\
\hline DV & 0.43 & 0.09 & 0 & 0.5 & 0 & 1 \\
\hline $\mathrm{RD}$ & 0.07 & 0.05 & 0 & 0.25 & 0 & 1 \\
\hline BM & 11 & 0.65 & 10 & 3.55 & 7 & 23 \\
\hline $\mathrm{NIM}$ & 0.03 & 0 & 0.03 & 0.01 & 0.02 & 0.04 \\
\hline ROA & 0.01 & 0 & 0.01 & 0.01 & -0.02 & 0.02 \\
\hline ROE & 0.08 & 0.02 & 0.09 & 0.12 & -0.33 & 0.22 \\
\hline
\end{tabular}

For all the other variables used, we observe the mean and median value for each to be fairly close to each other suggesting the data is symmetrical about its mean and we can rule out skewness in the data. Variables NIM, ROA and ROE take values in terms of percentages with no upper limit while DC, GNPA, NNPA, WO, BI and ACI are expressed in percentage and cannot take values above 1 or $100 \%$. BKS taken as the normal log of total bank assets has been further normalized to take values between 0 to 1 . RD and DV take binary values of either 0 or 1 depending on whether these have been observed in a particular year in a bank.

\subsection{Correlation Result}

\begin{tabular}{|c|c|c|c|c|c|c|c|c|c|c|c|c|}
\hline & $\mathrm{BCO}$ & BKS & $D / C$ & GNPA & NNPA & $W / 0$ & $\mathrm{Bl}$ & $\mathrm{ACl}$ & ACS & DV & RD & $B M$ \\
\hline $\mathrm{BCO}$ & 1 & & & & & & & & & & & \\
\hline BKS & $\cdot 0.1$ & 1 & & & & & & & & & & \\
\hline$D / C$ & $-0,19$ & $\cdot 0.24$ & 1 & & & & & & & & & \\
\hline GNPA & 0.77 & 0.39 & $-0,1$ & 1 & & & & & & & & \\
\hline NNPA & 0.8 & 0.3 & .0 .08 & 0.97 & 1 & & & & & & & \\
\hline $\mathrm{W} / 0$ & 0.48 & 0.49 & $\cdot 0.15$ & 0.75 & 0.68 & 1 & & & & & & \\
\hline $\mathrm{Bl}$ & 0.05 & 0.46 & -0.56 & 0.22 & 0.2 & 0.29 & 1 & & & & & \\
\hline $\mathrm{ACl}$ & -0.79 & -0.21 & 0.06 & -0.71 & -0.72 & -0.51 & 0.1 & 1 & & & & \\
\hline ACS & -0.12 & 0.42 & $\cdot 0.14$ & -0.03 & $\cdot 0.06$ & -0.02 & -0.1 & $\cdot 0,38$ & 1 & & & \\
\hline DV & 0.44 & $\cdot-0.13$ & 0.05 & 0.3 & 0.29 & 0.04 & $\cdot 0.13$ & $\cdot 0,32$ & 0.02 & 1 & & \\
\hline RD & 0.67 & -0.02 & -0.21 & 0.65 & 0.58 & 0.36 & 0.07 & $\cdot 0.46$ & -0.04 & 0.31 & 1 & \\
\hline$B M$ & 0.18 & 0.35 & $\cdot 0.16$ & 0.28 & 0.14 & 0.59 & 0.05 & $-0,33$ & 0.22 & 0.29 & 0.08 & 1 \\
\hline
\end{tabular}

Toble 4: Pearson's correlation Matrix 
DOI: 10.14807/ijmp.v12i7.1473

The correlation matrix (depicted in table 4) has been developed to evaluate the correlations between the 12 independent variables that include both, governance metrics and other control matrix. From the above we observe that variables BCO, D/C, GNPA, NNPA, W/O show high correlation (>0.5 and <-0.5) with other independent variables indicating multicollinearity amongst the independent variables. Hence, in order to obtain a non-biased result, we have removed the highly correlated variables from the dataset. On running a fresh correlation test on the remaining 6 variables we observe no instance to have correlation $<-0.5$ or $>0.5$ (as indicated in table 5).

\begin{tabular}{ccccccc}
\hline & BKS & BI & ACl & ACS & DV & RD \\
\hline BKS & 1 & & & & & \\
BI & 0.46 & 1 & & & & \\
ACl & -0.21 & 0.1 & 1 & & & \\
ACS & 0.42 & -0.1 & -0.38 & 1 & & \\
DV & -0.13 & -0.13 & -0.32 & 0.02 & 1 & \\
RD & -0.02 & 0.07 & -0.46 & -0.04 & 0.31 & 1 \\
\hline
\end{tabular}

Table 5: Pearson's correlation Matrix

Table 5 shows that none of the remaining independent variables show high correlation with the other variables which means that by eliminating highly correlated variables we have ruled out multi-collinearity amongst our independent variables. We now test each of our dependent variables i.e. NIM, ROA and ROE against the independents to obtain the relationship. Results of the Multi-Variate Linear Regression are as follows.

\subsection{Regression Results}

\begin{tabular}{cccccccc}
\hline \multicolumn{7}{c}{ Adjusted } & Residual \\
S.No & Variable & R Square & R Square & SS & FValue & p Value \\
\hline 1 & ROE & 0.86 & 0.82 & 0.06 & 22.84 & 0 \\
2 & ROA & 0.8 & 0.74 & 0 & 15.01 & 0 \\
3 & NIM & 0.79 & 0.73 & 0 & 14.36 & 0 \\
\hline Table 6: Regression model output summary
\end{tabular}

Post the correlation analysis, multi-variate regression test was run keeping the bank's profits, denoted by NIM, ROE, ROA as the dependent variables, BI, ACI, and RD as the independent variables and BKS, ACS, DV signifying the control variables. Tables 6 and 7 show the summary output of the regression analysis. From table 6, we can observe that ROE has an adjusted R-square value of 0.82 , meaning $82 \%$ of variance in ROE is explained by the explanatory variables selected. The p-value is extremely small. Hence it is significant at $1 \%$ 
DOI: 10.14807/ijmp.v12i7.1473

level. The adjusted R-square value of ROA and NIM are 0.74 and 0.73 , meaning $74 \%$ and $73 \%$ change in ROA and NIM respectively are explained by the independent variables chosen. pvalue for ROA and NIM are extremely small and hence significant at $1 \%$ level.

Table 7 summarises the output for independent variables. In the equation for ROE, variables ACI and RD (p-value 0) are statistically significant at 1\% level. Variables BKS (pvalue 0.02 ) and $\mathrm{RD}$ (p-value 0.04 ) are statistically significant at $5 \%$ level.

\begin{tabular}{|c|c|c|c|c|c|}
\hline \multirow{8}{*}{ ROE } & & Coefficients & Standard Error & tStat & P-value \\
\hline & Intercept & 0.1 & 0.16 & 0.64 & 0.53 \\
\hline & BKS & -0.14 & 0.05 & -2.55 & $0.02^{* *}$ \\
\hline & BI & -0.2 & 0.2 & -1.05 & 0.31 \\
\hline & $\mathrm{ACl}$ & 0.18 & 0.04 & 4.26 & $0^{* * *}$ \\
\hline & ACS & 0.02 & 0.01 & 2.23 & $0.04^{* *}$ \\
\hline & DV & -0.01 & 0.02 & -0.5 & 0.62 \\
\hline & $\mathrm{RD}$ & -0.27 & 0.05 & -5.87 & $0^{* * *}$ \\
\hline \multirow{8}{*}{ ROA } & & Coefficients & Standard Error & t Stat & P-value \\
\hline & Intercept & -0.01 & 0.02 & -0.49 & 0.63 \\
\hline & BKS & -0.01 & 0.01 & -2.52 & $0.02^{* *}$ \\
\hline & BI & 0 & 0.02 & 0.13 & 0.89 \\
\hline & $\mathrm{ACl}$ & 0.02 & 0 & 5.08 & $0^{* * *}$ \\
\hline & ACS & 0 & 0 & 1.77 & $0.09^{*}$ \\
\hline & DV & 0 & 0 & -0.49 & 0.63 \\
\hline & $\mathrm{RD}$ & -0.01 & 0 & -2.86 & $0.01^{* * *}$ \\
\hline \multirow{8}{*}{ NIM } & & Coefficients & Standard Error & t Stat & P-value \\
\hline & Intercept & 0 & 0.01 & -0.24 & 0.82 \\
\hline & BKS & -0.01 & 0 & -2.63 & $0.02^{* *}$ \\
\hline & BI & 0.03 & 0.01 & 2.56 & $0.02^{* *}$ \\
\hline & $\mathrm{ACl}$ & 0.02 & 0 & 5.89 & $0^{* * *}$ \\
\hline & ACS & 0 & 0 & 1.7 & $0.1^{\circ}$ \\
\hline & DV & 0 & 0 & -0.38 & 0.71 \\
\hline & $\mathrm{RD}$ & 0 & 0 & -0.97 & 0.34 \\
\hline
\end{tabular}

Table 7: Regression output

In the equation for ROA, variables ACI (p-value 0) and $\mathrm{RD}$ (p-value 0.01) are statistically significant at $1 \%$ level. Variable BKS (p-value 0.02 ) is statistically significant at $5 \%$ level and ACS (p-value 0.09 ) is significant at $10 \%$ level. 
DOI: $10.14807 /$ ijmp.v12i7.1473

In the equation for NIM, variables ACI (p-value 0 ) is statistically significant at $1 \%$ level. Variable BKS (p-value 0.02) and BI (p-value 0.02) are statistically significant at 5\% level; whereas ACS (p-value 0.1 ) is significant at $10 \%$ level.

Through the above equations we observe that ACI is most significant in all the equations, this signifies that Audit Committee has a strong influence over a bank's profitability as a board with more independent directors focuses heavily on providing value to shareholders and hence they aim at improving the profits in order to achieve that goal. BKS is significant but negatively related to all three measures of bank profits thereby indicating that the larger the bank size the lesser it will be able to manage its costs thereby negatively affecting profits. RD is significantly related to ROE and ROA and indicates that absence of role duality leads to higher profits and vice versa. This observation furthers the agency theory that separation of the Chairman and CEO role enhances an organization's function by establishing accountability in the executive's role.

ACS is significant at varying levels across the three equations, suggesting that more members ensure adequate transparency being observed in terms of financial statement disclosures to regulators and public at large. Combining this with the high independence of the committee brings about a greater degree of transparency by ensuring all risks are adequately accounted and provided for.

\section{Discussions and Conclusion}

\subsection{Discussion}

Through this study, I have tried to bring a degree of newness by incorporating the variable DV and RD as a response variable. The rationale to include NPA Divergence (DV) was that it highlights the under reporting of bad loans by and bank as identified by the RBI and that it significantly alters Net Profit reported by banks as listed in the proforma prescribed by RBI. Divergence in banking parlance means the aggregate of NPAs of a bank which were not divulged by banks itself in order to portray its enhanced earnings before the stakeholders. Divergence generally is the amount of such NPAs which is identified by the regulator from the balance sheet of the Bank during inspection and evaluating the classification of assets as prescribed, as a part of its supervisory duties.

Role Duality (RD) refers to instance where the Chairperson of the organization also holds office as the Chief Executive, in essence playing the role of both, a maker and a checker. The core argument arises from the fact that Role duality creates a CEO/Chairperson who both 
INDEPENDENT JOURNAL OF MANAGEMENT \& PRODUCTION (IJM\&P)

http://www.ijmp.jor.br

v. 12, n. 7, September-October 2021

ISSN: 2236-269X

DOI: 10.14807/ijmp.v12i7.1473

steers board meetings, designs policy framework and implements them himself, thereby vesting him with power unrestrained from acting in his/her own self-interest. This is a problem as it significantly undermines the supervision of power and functions of the BOD and threatens the independent checks and balances which are essential to maintaining stringent internal control and good CG. In India, Companies Act 2013 and SEBI regulations mandate that companies and private banks separate these roles, in 2004-05 RBI committee under the chairmanship of A S Ganguly discussed implications of role separation for office of Chairman and Managing Director in banks. The panel had recommended the bifurcation.

In this study we observe that post the enforcement of the Companies Act, 2013; the Bank Size (BKS) and profit metrics are negatively correlated. One of the possibilities is that since all the banks in our sample are large in stature, they tend to have a larger Bank Size and hence it has a significant bearing on profits. From the results, it can be said that for banks, it is crucial to have an optimal BKS, as larger BKS may lead to more cost. Secondly, the positive and significant association between ACI and profit metrics tells us that compliance with the regulations specified in the Companies Act, 2013 does result in positive outcome in profits for the banks. ACI also ensured that true and fair reporting was followed and appropriate internal controls were placed to reduce exposure to risks. These findings boost confidence of shareholders and depositors. I find the result of ACI and profit to in agreement with the agency theory which lays emphasis on independence of audit committee for reduction in cost incurred to the agency.

\subsection{Conclusion}

This study was done across Axis, HDFC, ICICI, PNB, SBI and Yes Bank through the year 2014-15 to 2018-19 to empirically measure the impact CG factors held over bank profits which were denominated by ROA, ROE and NIM. From the data analysis, we conclude that parameters BKS, BI, ACI, ACS, DV, RD have a good amount of impact on the profits. Other dependent variable namely, DV (NPA Divergence) has proved to be statistically insignificant across all three profit variables. For ROE, we see that BKS, ACI, ACS and RD are statistically significant and hence are accepted to have an impact on ROE. We see that RD has a negative affiliation to ROE, meaning role duality leads to lower profits and vice-versa. In respect of ROA we observe variables BKS, ACI and RD to be statistically significant (p-value $<0.05$ ). In respect of ROA variables BKS, ACI, and RD are observed to be statistically significant, with RD showing negative affiliation with ROA. BKS, BI and ACI variables are statistically 
DOI: 10.14807/ijmp.v12i7.1473

significant in determining NIM of a bank. BKS is negatively affiliated to NIM meaning greater the bank size the lower NIM it will register.

The contribution of this research has been to recognize the most important governance parameters that banks must focus on to comply with the regulations and make profits in order to increase their shareholder value and stakeholder perception value. Focussing on these aspects can help companies identify and implement stricter measures to monitor these areas thereby reducing scope of governance lapses and the after effects of such lapses as has been evidenced in the case of PNB and Yes Bank.

\section{Limitations and Future Scope}

The study was limited to a sample of banks where in 4 were identified to have been involved in a series of compliance breaches with respect to the Clause 49 of Listing Agreement, SEBI, RBI and Companies Act 2013 regulations. The results of this study are derived from the data of the impact period that followed the amendments in the CG landscape for Indian Banks with the amendment in Companies Act, 2013, SEBI LODR, 2015, and RBI norms. Future studies may carry forward the results over a longer time period, across a larger sample. Further researches could include the gender distribution factor as well which will include the quantum of female directors and other critical committees, which was missing owing to unavailability of data on gender in the Prowessdx database by CMIE.

\section{REFERENCES}

Balasubramaniam, C. S. (2001). Non-Performing Assets and Profitability of Commercial Banks in India : Assessment and Emerging issues. Abhinav Journal, 1(7), 91.

Brahmaiah, B., \& Ranajee. (2018). Factors Influencing Profitability of Banks in India. Theoretical Economics Letters, 08(14), 3046-3061.

https://doi.org/10.4236/tel.2018.814189

Chaudhary, K., \& Sharma, M. (2011). Performance of Indian Public Sector Banks and Private Sector Banks: A Comparative Study. International Journal of Innovation, Management and Technology, 2(3), 1. http://www.ijimt.org/papers/140-M582.pdf Enobakhre, A. (2010). Corporate governance and bank performance in Nigeria. MBA Research Report, University of Stellenbossch, 1. http://hdl.handle.net/10019.1/8439 Fanta, A. B. (2013). Corporate Governance and impact on Bank Performance. Journal of Finance and Accounting, 1(1), 19. https://doi.org/10.11648/j.jfa.20130101.12

Goel. (2014). Impact of Corporate Governance on Non Performing Assets in Banks. Impact of Corporate Governance on Non Performing Assets in Banks, 4(3), 15-28.

https://www.indianjournals.com/ijor.aspx?target=ijor:zijbemr\&volume=4\&issue=3\&article= 002 
INDEPENDENT JOURNAL OF MANAGEMENT \& PRODUCTION (IJM\&P)

http://www.ijmp.jor.br

v. 12, n. 7, September-October 2021

ISSN: 2236-269X

DOI: 10.14807/ijmp.v12i7.1473

HifzaInam, \& Mukhtar, A. (2014). Corporate Governance and its Impact on Performance of Banking Sector in Pakistan.

Joseph, A. L., \& Prakash, M. (2014). A Study on Analyzing the Trend of NPA Level in Private Sector Banks and Public Sector Banks. International Journal of Scientific and Research Publications, 4(7), 1. http://www.ijsrp.org/research-paper-0714/ijsrp-p3145.pdf

Kanungo, \& Dash. (2016). Conceptual view on Companies Act 2013: with special reference to Share Capital.

https://www.researchgate.net/publication/328262628_A_CONCEPTUAL_VIEW_ON_COM PANIES_ACT_2013_WITH_SPECIAL_REFERENCE_TO_SHARE_CAPITAL

Kumari, P., \& Pattanayak, J. K. (2017). Linking earnings management practices and corporate governance system with the firms' financial performance. Journal of Financial Crime, 24(2), 223-241. https://doi.org/10.1108/jfc-03-2016-0020

Narwal, K. P., \& Pathneja, S. (2016). Effect of bank-specific and governance-specific variables on the productivity and profitability of banks. International Journal of Productivity and Performance Management, 65(8), 1057-1074. https://doi.org/10.1108/ijppm-09-2015-0130

Nworji, I. D., Adebayo, O., \& Adeyanju, O. D. (2011). Corporate Governance and Bank Failure in Nigeria : Issues, Challenges and Opportunities. Research Journal of Finance and Accounting, 24.

http://citeseerx.ist.psu.edu/viewdoc/download?doi=10.1.1.946.8112\&rep=rep1\&type=pdf

Nyor, T. (2013). Impact of Corporate Governance on Non-Performing Loans of Nigerian Deposit Money Banks. Journal of Business \& Management, 2(3), 12-21.

https://doi.org/10.12735/jbm.v2i3p12

P. (2014, May 9). Better corp governance helps pvt banks limit NPAs. BusinessLine. https://www.thehindubusinessline.com/economy/\%60Better-corp-governance-helps-pvtbanks-limit-NPAs\%E2\%80\%99/article20768600.ece

Pati, A. P. (2006). Does Corporate Governance Matter in Indian Banking? Policy Implications on the Performance. Indian Institute of Capital Markets 9th Capital Markets Conference.

Paul, A. A., \& Simon, K. M. (2014). The Impact of Corporate Governance Variables on Non-performing Loans of Nigerian Deposit Money Banks. 1531-1544.

Prasad, G. V. B., \& Veena, D. (2011). NPAs Reduction Strategies for Commercial Banks in India. International Journal of Management \& Business Studies, 1(3), 47.

http://www.ijmbs.com/13/bhawani.pdf

Rajwade, A. V. (2014, August 27). Corporate governance and NPAs. Mint. https://www.livemint.com/Opinion/3KcW1bj41Cf4vv4Kh43oNM/Corporate-governanceand-NPAs.html

Reserve Bank of India. (2020, June 11). Discussion paper on Governance in Commercial Banks in India. https://m.rbi.org.in/Scripts/PublicationsView.aspx?id=19613

Venkateshwaran, S., Rastogi, R., \& Arora, P. (2018, May). SEBI implements Kotak Committee recommendations. KPMG India.

https://assets.kpmg/content/dam/kpmg/in/pdf/2018/05/vor-special-session-sebi-implementskotak-committee-recommendations.pdf 
DOI: 10.14807/ijmp.v12i7.1473

Yangyou Zhen, R. (2010). China Commercial Bank Risk Aversion and Ownership Structure: Based on the Panel Data and Evidence. 33-39.

Zafar, S. M. T., Maqbool, A., \& Khalid, S. M. (2013). Non-Performing Assets and its Impact on Indian Public Sector Banks. 